\title{
Conceptual tendencies to analyze coal-gas system state under the hydroimpulsive effect
}

\author{
Kostiantyn Sofiiskyi ${ }^{1}$, Vasyl Zberovskyi ${ }^{1 *}$, Anatolii Yalanskyi $^{1}$, and Oleksii Yalanskyi ${ }^{2}$ \\ ${ }^{1}$ Institute of Geotechnical Mechanics named after M.S. Polyakov of the National Academy of \\ Sciences of Ukraine, 2a Simferopolska St., 49005 Dnipro, Ukraine \\ ${ }^{2}$ Dnipro University of Technology, Department of Underground Mining, 19 Yavornytskoho Ave., \\ 49005 Dnipro, Ukraine
}

\begin{abstract}
The paper considers conceptual tendencies concerning the analysis of coal-gas system state within rock mass in front of a mine working stope in the context of hydroimpulsive effect on an outburst-prone coal seam. It has been shown that mining intensification is impossible without the improved efficiency of means indented to avoid gasdynamic phenomena taking into consideration the effect of technogenic factors on operation schedules. It has been determined that since grades of outburstprone coal are of globular structure, its breakage may involve changes in molecular weight of coal substance and generation of methane and water molecules. In the context of a shear model of undermined rock mass, method of graphical analysis has been applied to determine areas of changes in border angles of demonstration of the initial and maximum deformation under the effect of rock bearing pressure. The determined dependences are described rather reliably by means of similar logarithmic curves which characterizes identity of their nature. Changes in filtration coal characteristics in the context of shear deformations have been considered. It has been proved experimentally that if injection pressure varies, periodically discontinuous fluid flow has initial, stable, and decaying stages being implemented in the forms of cavitation phenomena and high-frequency hydroimpulsive vibration. Sequence of methods to study parameters of hydroimpulsive action, evaluation of its efficiency, and control over a change in coal-gas system state of outburst-prone coal seams have been considered.
\end{abstract}

\section{Introduction}

A problem to avoid sudden coal and gas outbursts, arising during extraction of outburstprone coal seams, is still among the most complicated and topical. During decades, effect of technogenic factors is under study. It is known that the closest conditions are created within high rock pressure areas on unprotected coal seams where spontaneous coal self-destruction takes place in roadheads $[1,2]$. The phenomenon is under constant study; however, certain problems are of debating nature [3].

\footnotetext{
*Corresponding author: avalansh@ua.fm
} 
Consideration of changes in coal-gas seam from the viewpoint of interaction between solid and gaseous components of coal-gas system has helped solve a number of research and practice problems. For instance, gasdynamic coal self-destruction is used effectively in the context of hydrodynamic action by means of wells, drilled through rock or in the context of hydraulic loosening, modes of impulsive liquid injection is the most effective measure $[4-6]$.

Paper [6] has considered in what way shear deformations and change in stress-strain state of a coal seam effect performance capability of hydrodynamic action. At the same time, effect of technogenic factors on the initiation of self-destruction and gas-emission processes is still understudied. Injection pressure involving pressure of a seam hydraulic loosening depending upon the depth of a well hermetization was not determined which would help identify border value of injection pressure. Processes of change in coal-gas system state under the effect of shear deformations within geological formation in front of a stope of development mine working are understudied; there are no procedures to calculate parameters and methods to control hydroimpulsive action.

Thus, the use of normative techniques to avoid hydrodynamic phenomena (HDP) in stopes of the development mine workings not always provides mining safety and needs shock blasting in dangerous zones. That consumes more cost and time to mine coal. Moreover, velocity of mine workings construction drops from 6 down to 2 meters a day.

Objective of the paper is to determine conceptual tendencies of coal-gas system state analysis in the context of hydroimpulsive action on outburst-prone coal seams which will help intensify operation schedules and improve operation safety.

\section{The basic content of the paper}

To achieve the stated objective, following analyses of the research results were performed: structural and textural framework, composition, and technological characteristics of coal; surface of coal as separation border of environments; hypotheses of changes in coal-gas system state in outburst-prone coal seams; means and measures to avoid HDP and improve deep mining safety. The obtained data helped formulate the basic conceptual solutions and substantiate the research tendencies.

\subsection{Analysis of coal-gas system components and its transformation under the effect of technogenic factors}

In terms of $l_{3}$ seam, being common for Donetsk coal field, and elements of carbon, hydrogen, and oxygen, being their components, average structural formulas of their composition at different carbonification stages was considered. It is known that changes in coal structure are followed by rejection of simple matters in the form of $\mathrm{H}_{2} \mathrm{O}$ and $\mathrm{CH}_{4}$. Thus, changes in molecular weight of coal components make it possible to consider stages of its transition from one grade to another (Table 1) [6].

It is also known that carbonification process is followed by certain change in interaction between coal components and transformation processes in its supermolecular arrangement (SMA). Assume that in a chemical SMA change it is reflected by means of double $\mathrm{C}=\mathrm{C}$ bonds of carbon of crystalline share of macromolecule and breaking of single bonds of carbon, hydrogen, and oxygen within the layers of side radicals of amorphous structures. Thus, conditions, under which new molecules of water and methane originate, are being formed within coal-gas system. The assumption is supported by sudden increase in gas amount under hydrodynamic action or during self-destruction processes of the most outburstprone and unstable coal grades (i.e. $\mathrm{K}$ and $\mathrm{Z}$ ) which SMA structure of macromolecule is 
considered as globular [6]. Hence, tendency one to analyze components of coal-gas environment and its structure has been identified.

Table 1. Element composition of different coal grades in terms of seam $l_{3}$ of Donetsk coal field.

\begin{tabular}{|l|c|c|c|c|c|}
\hline \multirow{3}{*}{ Coal grade } & \multicolumn{5}{|c|}{ Element composition of $l_{3}$ seam } \\
\cline { 2 - 6 } & \multicolumn{2}{|c|}{ Element composition, \% } & \multicolumn{2}{c|}{ Formula and weight } \\
\cline { 2 - 6 } & $C^{\text {daf }}$ & $H^{\text {daf }}$ & $O^{\text {daf }}$ & formula & molecular weight \\
\hline Hazovyi - H & 80.00 & 5.60 & 14.40 & $\mathrm{C}_{37} \mathrm{H}_{31} \mathrm{O}_{5}$ & 554.67 \\
\hline Koksivnyi - K & 88.70 & 5.30 & 6.00 & $\mathrm{C}_{97} \mathrm{H}_{69} \mathrm{O}_{5}$ & 1314.66 \\
\hline Zhyrnyi - Z & 89.00 & 5.50 & 9.50 & $\mathrm{C}_{62} \mathrm{H}_{46} \mathrm{O}_{5}$ & 872.94 \\
\hline Toshchyi - T & 92.40 & 3.80 & 3.80 & $\mathrm{C}_{96} \mathrm{H}_{47} \mathrm{O}_{3}$ & 1248.43 \\
\hline Antratsyt - A & 95.0 & 2.0 & 3.0 & $\mathrm{C}_{52} \mathrm{H}_{12} \mathrm{O}$ & 620 \\
\hline
\end{tabular}

\subsection{Analysis of factors initiating changes in coal-gas system state within geological formation}

It is known that changes in coal-gas system state within geological formation take place under the effect of technogenic factors connected with shear parameters of the undermined rock mass [7 - 11]. Basing upon a method of graphical calculations, research findings [12] have determined border angles of deformations $\delta_{0}$ manifestations as well as slopes of a curve of development of maximum deformations which correspond to rock burst angles $\delta^{\prime \prime}$ [13].

If we assume that the determined border angles of deformations $\delta_{0}$ manifestation correspond approximately to a stage of transformation stage origination within coal-gas system and curve of development of maximum deformations $\delta^{\prime \prime}$ corresponds to its ending stage, it is possible to identify rock mass areas within which transformation processes take place under the effect of mining operations. For instance, Fig. 1 demonstrates superimposed curves characterizing dependences of border angles of deformations $\delta_{0}$ manifestation as well as the development of maximum deformations $\delta^{\prime \prime}$ within the undermined rock mass upon the distance between seams $h$.

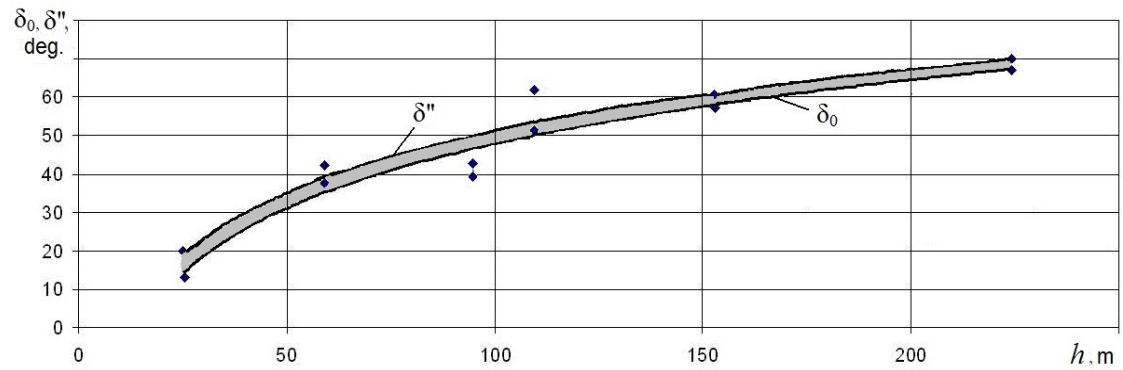

Fig. 1. Area of rock bearing pressure change determined temporally and spatially where transformation conditions of outburst-prone coal are formed within the undermined geological formation: $\delta_{0}$ - a curve characterizing dependence of the manifestation of border angles of the initial deformations; and $\delta^{\prime \prime}$ - a curve characterizing dependence of the development of maximum deformations upon distance between seams.

Similar logarithmic curves describe the determined dependences quite reliably. Dependence of a curve, characterizing initial stage of stress origination, is:

$$
\delta_{0}=24.39 \ln (h)-63.77 \text { if } R^{2}=0.94,
$$


and a curve, characterizing maximum stresses, is

$$
\delta^{\prime \prime}=23.2 \ln (h)-56 \text { if } R^{2}=0.92 .
$$

$0.92-0.94$ determination coefficient means that mining and geological conditions, and rock shear parameters have rather high correlation. Thus, the obtained results make it possible to consider mining effect on the change in gasdynamic state of outburst-prone seams within rock mass being undermined and overmined.

Hence, analysis of the change in the intensity of velocity of gas emission from control borehole as well as nature of deformation demonstration within adjacent seams [12] helps determine de-stressed zone and zones of origination and manifestation of maximum stresses within which rock blocks are formed in geological formation, and shear of the undermined rock mass takes place. That makes it possible to determine temporal variations and spatial variations of rock bearing pressure area where transformation conditions of outburst-prone coal are being formed.

The obtained results have helped substantiate research tendency two analyzing shear processes of the undermined rock mass and factors effecting changes in coal-gas system state within rock mass.

\subsection{Analysis of a state of outburst-prone seam in front of a roadhead}

During the process of implementing measures to avoid sudden outbursts of coal and gas, changes in the state of outburst-prone seam is controlled according to th initial velocity of gas emission; effect of technogenic factors is not involved [10]. Therefore, analysis of the additional loading of coal-gas system by coal destruction with the help of coal shearer, drilling and blasting operations, drilling of advance wells, hydrodynamic or hydroimpulsive procedures is another tendency.

Consider the known scheme of changes in the state of coal seam located in front of a roadhead under the effect of rock pressure (Fig. 2).

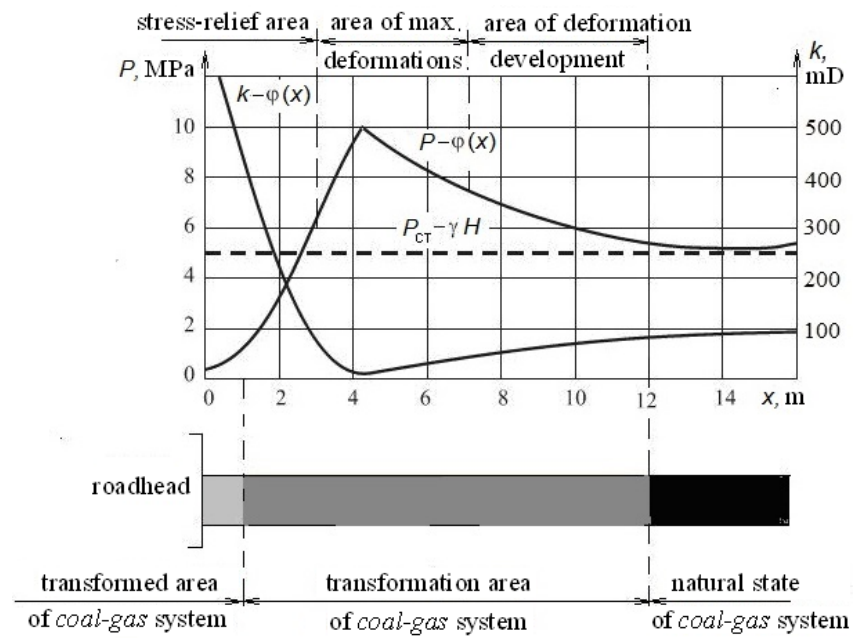

Fig. 2. Scheme of coal seam transformation areas and its filtration characteristics under the effect of technogenic factors in front of a roadhead.

As it is understood, when rock bearing pressure varies in front of a roadhead, similar processes take place within coal seam. If pressure, corresponding to transformation zone, 
increases, filtration characteristics of coal decrease and increase sharply within de-stressed seam zone after demonstration of shear deformations.

The conclusion is important in the process of seam hydraulic loosening since when liquid is being injected, load of its pressure is added. At the same time, calculation of injection parameters does not involve the fact; thus, uncontrolled processes of hydraulic loosening or water inrush. Moreover, taking into account the assumption that in the process of coal breaking down, macromolecule of coal substance may generate methane molecules, liquid pressure is added by pressure of gaseous component of coal-gas system. Hence, complicated conditions are being formed within the working area of a seam. Until now the conditions remain unexamined. Model by O.M. Dynnyk $\left(\sigma_{y}=\gamma H\right)$ is a generally accepted hypothesis for the formation of stress-strain state of a coal seam. The hypothesis assumes that pressure is developed by rock mass which height is equal to mining depth $H$. According to the theory, in the context of hydraulic loosening, liquid injection pressure is determined on the formula $P_{i}=(0.75 \ldots 1.0) \gamma H$; for hydraulic loosening, $P_{i} \geq 0.75 \gamma H$ formula is applied where empiric coefficient takes into account every other factor [14]. At the same time, it is known that in the context of deep depths, lamination zones are formed within geological formation if block theory is used. Thus, stress-strain state of a coal seam varies. Papers [7, 15] consider the features while analyzing boundary state of outburstprone coal seam; however, they should be determined for other mining and geological conditions.

\subsection{Methods to analyze changes in the state of coal-gas system in the context of hydroimpulsive effect}

To study the tendency, both natural and technogenic factors, under which effect coal-gas systems transforms from the edge of outburst-prone coal seam into safe state, have been considered successively. The factors are as follows: parameters of hydroimpulsive action device, and its equipment; modeling results of periodically discontinuous fluid flow using simulator of filtration part of a well, and analysis of dynamic parameters of coal seam loading; and methods to control and evaluate efficiency of hydroimpulsive action within the stopes of development mine workings. Paper [15] has considered successively: substantiation of parameters of impulse modes of coal seam loading; a model of engineering approach to calculate cavitation auto-oscillations; and substantiation of a working range of dynamic parameters of impulsive loading.

Such research makes it possible to substantiate scientifically parameters of hydroimpulsive action. It is known that coal and its shear resistance is characterized by the coefficients of internal friction and external friction. However, support literature does not contain sufficient information concerning its parameters [5]. Taking into account the fact, that hydroimpulsive action factors into changes in coal strength parameters, a method to determine them have been developed. For the first time, outburst-prone coal samples were applied for experiments intended to identify compressive loads and breaking loads adding to stratification either vertically of horizontally. That helped define independence of shear fissuring from loading direction. Coal from outburst-prone seams $i_{3}{ }^{1}$ and $k_{2}{ }^{l}$ was sampled. It has been defined that if shear is loaded perpendicularly and vertically to stratification, difference in the values of internal friction angles is almost $1 \%$ being in the range of measurement error. Hence, in the context of outburst-prone coal, being of globular structure, the force, initiating shear fissuring, cannot depend upon loading direction (Fig. 3). In terms of the coal samples from the central coal bench of seam $k_{2}{ }^{l}$, coefficients of internal pressure $\mu$ are 0.95 and 0.96 ; angles of internal friction $\rho$ are 43.5 and 43.8 degrees respectively. 
Following problem concerns a mechanism to transfer pressure impulses to a coal seam being considered from the viewpoint of the varied stress state in the neighbourhood of a well. It is amounted to static and dynamic boundary problems of elasticity theory. Paper [16] explains results of the studies.

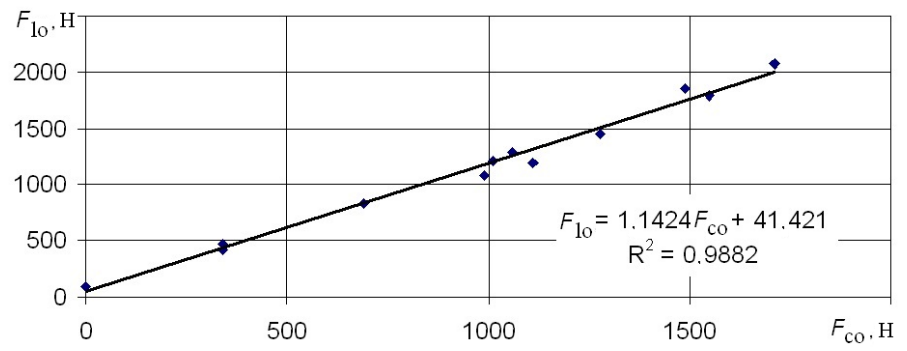

Fig. 3. Analytical dependence of shear loading $F_{l o}$ upon compressive loading $F_{l o}$ for outburst-prone coal.

The stresses, resulting from impulsive injection, are determined by means of static component $p_{s t}$, and dynamic component $p_{\text {din }}$ :

$$
\begin{gathered}
p=p_{s t}+p_{\text {din }}, \\
p_{s t}=\bar{p}=\left(p_{\max }+p_{\min }\right) / 2, p_{\text {din }}=0.5 \Delta p \cos (\omega t), \Delta p=p_{\max }-p_{\min } .
\end{gathered}
$$

Calculation of the arising radial stresses is amounted to the solution of two boundary problems of elasticity theory. Static component is determined with the help of Lame solution:

$$
\sigma_{r r}^{(s t)}(r)=\frac{a^{2}}{r^{2}} p_{s t}
$$

and dynamic component is determined by means of a solution of a problem of harmonic loading of a well surface within infinite elastic medium

$$
\sigma_{r r}^{(d i n)}(r)=-0.5 \Delta p \frac{2 b r^{-1} H_{1}^{(2)}\left(k_{1} r\right)-k_{1} H_{0}^{(2)}\left(k_{1} r\right)}{2 b a^{-1} H_{1}^{(2)}\left(k_{1} a\right)-k_{1} H_{0}^{(2)}\left(k_{1} a\right)},
$$

where $H_{n}^{(2)}\left(k_{1} r\right)$ is Hankel function; $k_{1}=2 \pi f \sqrt{\rho(1+v)(1-2 v) / E(1-v)}$ is the number of longitudinal waves; $\rho$ is mass density, $\mathrm{kg} / \mathrm{m}^{3} ; v$ is Poisson's ratio; $E$ is elasticity modulus, $\mathrm{MPa} ; f$ is frequency of harmonic action on a well surface, $c^{-1}$; and $b=(1-2 v) / 2(1-v)$.

The following has been determined as a result of solving the problems: distribution of radial and maximum (in terms of modulus) stresses in the neighbourhood of the well; dependences of stresses upon radial distance to the well axis for different coefficients of side pressure; dependence of the dynamic stress component in terms of different Poisson's ratios and radial stresses; effect of coal seam boundaries on the distribution of radial fissures; and change in stresses corresponding to fracture development in the direction of rocks.

Methods, controlling the parameters of hydroimpulsive action, have been considered in the process of the deep underground experiments in Krasnodonvuhillia PJSC mines. The experiments were carried out in 8 stopes of the development mine workings in terms of 35 cycles of hydraulic loosening, performed according to normative methods, and 30 cycles in a mode of impulsive liquid injection. More than $1.2 \mathrm{~km}$ of mine workings were driven. 
Mining safety was evaluated by means of hydraulic loosening comparison in the context of static liquid injection, and impulsive one according to the results of control over gasdynamic state of a coal seam within a stope using the normative control methods: according to the initial velocity of gas emission from a test borehole; according to the control over acoustic signal by APSS-1 system; and according to the control over acoustic emission by ZUA-98 facilities.

Table 2 demonstrates an example of comparison of static and impulsive modes of hydraulic loosening.

Table 2. Parameters of hydraulic loosening of seam $\mathrm{k}_{2}{ }^{l}(617 \mathrm{~m} \mathrm{level})$ in a stope 33 of eastern Orlovskyi conveyor passage in Molodohvardiiska mine.

\begin{tabular}{|c|c|c|c|c|}
\hline \multirow{2}{*}{ Injection mode } & \multicolumn{3}{|c|}{ Hydraulic loosening parameters (average value) } \\
\cline { 2 - 5 } & $\begin{array}{c}\text { injection pressure, } \\
\mathrm{MPa}\end{array}$ & $\begin{array}{c}\text { injection period, } \\
\mathrm{min}\end{array}$ & $\begin{array}{c}\text { water amount, } \\
\mathrm{m}^{3}\end{array}$ & $\begin{array}{c}\text { Specific liquid } \\
\text { consumption, } l / \mathrm{t}\end{array}$ \\
\hline static & $14.0-18.0$ & 36.2 & 1.42 & 19.5 \\
\hline impulsive & $13.0-14.0$ & 9.2 & 0.52 & 7.0 \\
\hline Efficiency: & $74.6 \%$ & $63.4 \%$ & $64.1 \%$ \\
\hline
\end{tabular}

The results help mention that in the context of impulsive injection, active processing period is more than two times shorter and liquid consumption drops down to $60 \%$. Stressrelief area of the seam boundary deepens down the depth of technological well drilling. Within the processed area, velocity of gas emission for the test boreholes along the stope and in the directions of final boundary of the mine working decreases down to "traces" size and methane content within mine working atmosphere, when coal shearer breaks down coal, is not more than $1.0 \%$.

One of the key problems to be solved under industrial conditions was to determine a criterion to control hydroimpulsive action according to pressure of liquid damming within filtration share of a well. Taking into consideration complexity of visual recording of the intermediate pressure indices by a manometer, filming was applied. Then, MS Excel was used for graphic presentation of liquid pressure oscillations with $0.25 \mathrm{~s}$ interval (Fig. 4).

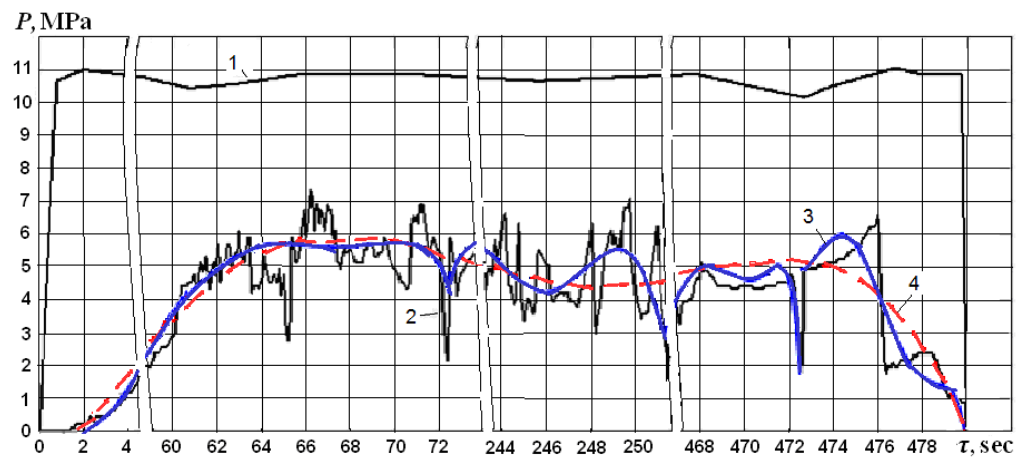

Fig. 4. Example of injection pressure recording (curve 1) and liquid damming within filtration share of the well (curve 2); and 3,4-trend lines

Analysis of the research results has shown that hydroimpulsive action process involves the initial stage, active stage, and final stage. At the initial stage, water fills up filtration share of a well. Then, under the stable pressure at the generator input ( $P_{i}=$ const), steady oscillations of liquid pressure within $2.0-7.0 \mathrm{MPa}$ are observed in a filtration share of the well, meaning that intensive fissure formation process takes place in its neighbourhood 
characterizing active hydraulic loosening stage. Then, after $6-8$ minutes, sharp pressure drop (down to $1.0-2.0 \mathrm{MPa}$ ) happens. The stage characterizes completion of hydroimpulsive action.

In accordance with the criterion of hydraulic loosening control, the process is considered as complete if the value of the highest determined value of liquid injection pressure, i.e. pressure of hydraulic resistance in a well, decreases by $30 \%$ at least. In our situation, decrease in the pressure of hydraulic resistance of a seam is $70 \%$.

Evaluation of the mining safety according to the control by APSS-1 system has shown that in the context of impulsive injection, stress-relief area is larger than the area of a well hermetization (being $4.0 \mathrm{~m}$ ), and achieves $6-7 \mathrm{~m}$. Upon that, at the distance of more than $10 \mathrm{~m}$ deformation development within the seam roof is observed providing uniform (i.e. with no lags) redistribution of stresses in the coal seam supporting labour safety as for the factor of sudden coal outbursts and gas emissions. To make the area safe continuously, measures should be taken in $6-7 \mathrm{~m}$ which corresponds to drilling depth of technological wells. According to the results of mining control by ZUA-98 facilities, it has been determined that accompanying sound of hydroimpulsive action helps control injection process as well as fissure formation process. Well drilling under the control of ZUA-98 helps control stress-relief area as well as high pressure area in front of a stope of a mine working. The obtained results made it possible to determine the following: at the depth down to $6.0 \mathrm{~m}$, AE impulses are not available which confirms complete rock mass destressing within processing area; hydroimpulsive action should be applied when coal seam is stressed out of stress-relief area at $3.5-4.5 \mathrm{~m}$ distance from a mine working stope; the higher stress concentration within rock mass is, the more efficient action of high frequency oscillations of GK-2.5 generator is; and if there is no unsafe state of rock mass, hydroimpulsive should not be involved.

The last tendency is to determine change in stress-strain state (SSS) of boundary area of a coal seam according to the results of underground experiments. Taking into consideration lack of methods to control structural transformations within coal seam, changes in SSS of rock mass, filtration of liquid and methane, the research is carried out using numerical modeling [17 - 22].

Mining safety as for SSS change was evaluated with the help of transient iterations $i$ by means of comparison of geomechanical parameter $Q=\left(\sigma_{1}-\sigma_{3}\right) / \gamma h$ characterizing a degree diverse-component stress field in the context of static and impulsive liquid injection [23].

It has been determined that if injection mode is static, a zone of nonelastic deformations is practically nonavailable. If hydroimpulsive action is applied, with a course of time diverse-component area $Q$ increases and zone of nonelastic deformations is formed within which Coulomb-Mohr failure criterion is performed as well as $P=\sigma_{3} / \gamma H<0.1 \ldots 0.3 \sigma_{s t} / \gamma H$ parameter characterizing it as a fissure formation area, and area of coal permeability sharp increase. Wet areas with pushed back methane are characterized by $p / p_{0} \geq 1$ isobars $(p$ is methane filtration parameter). If hydroimpulsive action takes place, then the area, where $p / p_{0}<1$, is quite larger. Hence, methane is filtrated faster. The conclusion is supported by the experimental results of the initial stage of gas emission from the test boreholes in stopes of the development mine workings (Fig. 5).

The obtained research results made it possible to develop a method of hydroimpulsive loosening of outburst-prone coal seams as well as a method to carry out its industrial tests under the most complicated conditions of heavy dip in the context of drilling-and-blasting mine working construction. The industrial tests were carried out in a stope of a haulage gate of level $1146 \mathrm{~m}$ of seam $l_{6}$ of "Tsentralna" Mine "Toretskvuhillia" SE.

The activities, intended for hydroimpulsive seam loosening, used parameters of hydroimpulsive action determined during underground experiments under the conditions of "Krasnodonvuhillia" PJSC mines: well drilling depth $-\ell=6.0 \mathrm{~m}$; diameters of wells - 
$d=42-45 \mathrm{~mm}$; well hermetization depth $-\ell_{\mathrm{g}}=4.0 \mathrm{~m}$; liquid pressure at generator input $P_{i}=20-23 \mathrm{MPa}$, corresponding to $1000-1200 \mathrm{~m}$ depth of the seam occurrence; and hydraulic loosening period $-t=10 \mathrm{~min}$. Efficiency control over the decrease in the velocity of the initial gas emission from test boreholes- up to $1.0 \mathrm{l} / \mathrm{min}$.

$a$

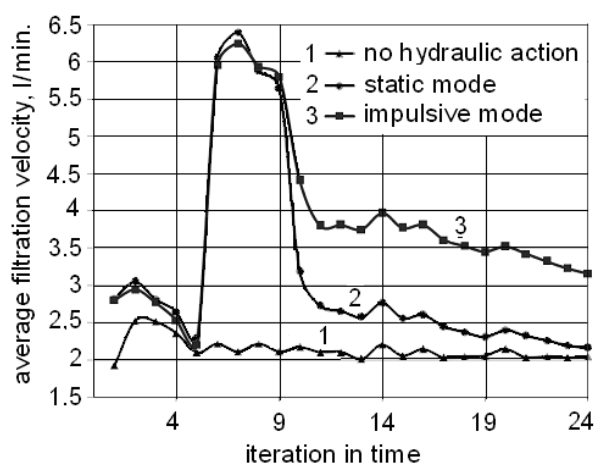

$b$

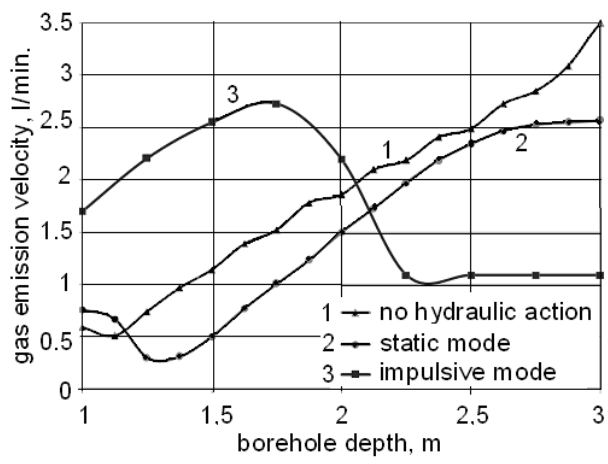

Fig. 5. Results of theoretical studies of the filtration velocity by a finite element method (a) and instrumental measuring of gas emission from the control boreholes (b).

Forecast control over outburst proneness in terms of the initial velocity of gas emission has determined that safe area of coal extraction before drilling and blasting operations (DBO) in a mode of shock blasting is 2 to $2.5 \mathrm{~m}$; in this context, initial gas emission velocity is more than $20 \mathrm{l} / \mathrm{min}$.

Five cycles of hydroimpulsive seam loosening have been developed according to the determined parameters of the method over $100 \mathrm{~m}$ of a mine working construction. In accordance with "Rules" [14], and "Methods to carry out industrial tests...", the initial gas emission velocity was studied. The results of the method control have helped define that after 10 min hydroimpulsive action, velocity of gas emission from the test boreholes at up to $3.5 \mathrm{~m}$ depth drops down to "traces" index. After blasting operation were performed within the area, effected by hydroimpulsive action at the distance of $6-7 \mathrm{~m}$, corresponding to three cycles of DBO, no signs of HDP were identified.

Hence, the industrial tests have determined that the accepted parameters of the method correspond to technological and geological conditions of occurrence of steep seams which supports efficiency of hydroimpulsive action and the determined tendencies to study changes in the state of coal-gas system of outburst-prone seams.

\section{Conclusions}

Relying upon the obtained theoretical studies, laboratory studies, and experiments, carried out under industrial conditions, following tendencies concerning analysis of the state of coal-gas system within geological formation of rocks, and in front of a stope of as mine working have been determined:

1. Analysis of components of coal-gas system, and its transformation under the effect of technogenic factors basing upon the hypothesis of gasdynamic state of the coal-gas system of outburst-prone seams formed naturally.

2. Analysis of the factors initiating change in the state of coal-gas system within the geological formation under the effect of shear deformations of rocks.

3. Analysis of pre-face share of outburst-prone seam in the context of additional loading of coal-gas system in the form of coal breaking down by means of coal shearer, BDO, 
drilling of advance wells, hydrodynamical or hydroimpulsive action, and while taking measures to avoid sudden coal outbursts and has emissions.

4. Development and improvement of methods to analyze change in the state of coal-gas system in the process of hydroimpulsive action on outburst-prone coal seams basing upon the results of stand tests of hydroimpulsive action device, comparison of the efficiency of hydraulic loosening in the context of static and impulsive liquid injection in stopes of mine workings, and mining safety evaluation according to normative control methods.

5. Determination of change in stress-strain state of border part of coal seam relying upon the results of underground experiments with the use of numerical modeling.

The developed research tendencies as well as results of underground experiments have helped evolve a method of hydroimpulsive loosening of outburst-prone seams, and determine its future development.

The studies were performed as a part of the state-financed projects of Institute of Geotechnical Mechanics named after M.S. Polyakov: "Theoretical foundations of rock mass shear and control over deformation processes during underground coal mining" (State registration No. 0103U004307) and "Substantiation of methods to calculate parameters of hydroimpulsive action on coal seams" (State registration No. 0112U000493).

\section{References}

1. Timofeev, E.I., Mhatvari, T.Ya., Churadze, M.V., \& Ryzhkov, M.F. (2003). Metodika vybora optimalnykh parametrov gidrorykhleniya vybrosoopasnykh ugol'nykh plastov. Sbornik nauchnykh trudov Makeevskogo nauchno-issledovatel'skogo instituta. "Sposoby i sredstva sozdaniya bezopasnykh i zdorovykh usloviy truda v uholnykh shakhtakh”, (1), 81-90.

2. Boyko, Ya.N., Nikiforov, A.V., \& Rubinskyi, A.A. (2009). Povyshenie effektivnosti gidrorykhleniya vybrosoopasnykh ugolnykh plastov $\mathrm{v}$ podgotovitel'nykh vyrabotkakh i nishakh. Sbornik nauchnykh trudov Makeevskogo nauchno-issledovatel'skogo instituta, 2(24), 52-57.

3. Osnovy teorii vnezapnykh vybrosov uglya, porody i gaza. (1978). Moskva: Nedra.

4. Bulat, A.F., Sofiyskiy, K.K., \& Silin, D.P. (2003). Gidrodinamicheskoe vozdeystvie na gazonasyshchennye ugolnye plasty. Dnipropetrovsk: Polihrafist.

5. Zberovskiy, V.V., \& Kostandov, Yu.A. (2011). Predel'noe sostoyanie vybrosoopasnykh ugolnykh plastov pri ikh gidrorykhlenii s uchetom soprotivlyaemosti uglya sdvigu. Zbirnyk naukovykh prats Natsionalnoho Hirnychoho Universytetu, (36(2)), 36-43.

6. Sobolev, V.V., Polyashov, A.S., Zberovskiy, V.V., Anhelovskiy A.A., \& Chuhunkov, I.F. (2013). Sistema ugol-gas v uglevodorodakh ugolnogo genezisa. Dnipropetrovsk: Art-Press.

7. Zberovskiy, V., Bubnova, O., \& Babii, K. (2018). Specifics of hydro-loosening of coal seams with account of rocks displacement parameters. E3S Web of Conferences, (60), 00025. https://doi.org/10.1051/e3sconf/20186000025

8. Chetverik, M.S., \& Androshchuk, Ye.V. (2004). Teoriya sdvyzheniya massiva gornykh porod $i$ upravleniya deformatsionnymi protsessami pri podzemnoy vyemke uglya. Dnipropetrovsk: DneprVAL.

9. Chetverik, M.S., Bubnova, O.A., Babiy, K.V., \& Batur, M.O. (2016) Shvydkist rozvytku deformatsii u pidroblenomu hirskomu masyvi pry vyimanni korysnykh kopalyn na osnovi marksheiderskykh sposterezhen. Heotekhnichna Mekhanika, (130), 3-12.

10. Kovalevska, I., Barabash, M., \& Snihur, V. (2018). Development of a research methodology and analysis of the stress state of a parting under the joint and downward mining of coal seams. Mining of Mineral Deposits, 12(1), 76-84. https://doi.org/10.15407/mining12.01.076

11. Kovalevs'ka, I., Vivcharenko, V., \& Snigur, V. (2013). Specifics of percarbonic rock mass displacement in longwalls end areas and extraction workings. Annual Scientific-Technical Collection - Mining of Mineral Deposits 2013, 29-33. https://doi.org/10.1201/b16354-7 
12. Novichikhin, I.A., Kuleshov, V.M., \& Zaytsev, Yu.A. (1977). Ispolzovanie zashchitnykh pologikh plastov na shakhtakh Donbassa. Donetsk: Donbas.

13. HSTU 101.00159226.001-2003 (2004). Pravyla pidrobky budivel, sporud i pryrodnykh obiektiv pry vydobuvanni vuhillia pidzemnym sposobom (NPAON 10.0-1.01-03). Kyiv: Ministerstvo vuhilnoi promyslovosyi Ukrainy.

14. SOU 10.1.001740088.011:2005 (2005). Pravyla vedennia hirnychykh robit na plastakh, skhylnykh do hazodynamichnykh iavlyshch: Normatyvnyi dokument. Kyiv: Ministerstvo vuhilnoi promyslovosti Ukrainy.

15. Zberovskiy, V.V. (2015). Razvitie inzhenernogo metoda rascheta dinamicheskikh parametrov gidroimpulsnogo vozdeystviya. Heotekhnichna Mekhanika, (125), 110-121.

16. Snitser, A.R. \& Zberovskiy, V.V. (2015). Raspredelenie napryazheniy vokrug skvazhiny v ugolnom plaste pri impul'snom nagnetanii zhidkosti. Zbirnyk naukovykh prats Natsionalnoho Hirnychoho Universytetu, (48), 107-119.

17. Nasedkina, A.A., \& Iovane, G.A. (2008). A model for hydrodynamic influence on a multi-layer deformable coal seam. Computational Mechanics, 24(3), 379-389.

18. Aziz, K., \& Settari, A. (2004). Petroleum reservoir simulation. Moscow-Izhevsk: Institute of Computer Science.

19. Ikonnikov, M.Yu., Ikonnikov, Yu.R., Slashcheva, E.A., Slashchev, I.N., \& Yalanskiy, A.A. (2015). Matematicheskoe modelirovanie $v$ zadachakh otsenki effektivnosti i bezopasnosti gornykh rabot. Dnipropetrovsk: Natsionalnyi hirnychyi universytet.

20. Ikonnikova, N.A., Korsun, V.I., Slashchev, A.I., Yalanskiy. Aleks.A., Yalanskiy A.A. (2015). Modelirovanie i kontrol' dinamicheskikh protsessov $\mathrm{v}$ zadachakh otsenki sostoyaniya geotekhnicheskikh sistem. Dnipropetrovsk: Natsionalnyi hirnychyi universytet.

21. Bondarenko, V., Kovalevs'ka, I., \& Fomychov, V. (2012). Features of carrying out experiment using finite-element methodat multivariate calculation of mine massif - combined support system. Geomechanical Processes During Underground Mining - Proceedings of the School of Underground Mining, 7-13. https://doi.org/10.1201/b13157-3

22. Pivnyak, G., Dychkovskyi, R., Smirnov, A., \& Cherednichenko, Y. (2013). Some aspects on the software simulation implementation in thin coal seams mining. Energy Efficiency Improvement of Geotechnical Systems, 1-10. https://doi.org/10.1201/b16355-2

23. Bulat, A.F., Krukovskaya, V.V., \& Zberovskiy, V.V. (2013). Sravnenie parametrov svyazannykh protsessov izmeneniya NDS i filtratsii zhidkosti i gaza pri razlichnykh rezhimakh nagnetaniya vody v ugolnyy plast. Heotekhnichna Mekhanika, (108), 197-205. 